\title{
Hydrogen peroxide is an endothelium-derived hyperpolarizing factor in mice
}

\author{
Tetsuya Matoba, ${ }^{1}$ Hiroaki Shimokawa, ${ }^{1}$ Mikio Nakashima, ${ }^{2}$ Yoji Hirakawa, ${ }^{1}$ \\ Yasushi Mukai, ${ }^{1}$ Katsuya Hirano, ${ }^{3}$ Hideo Kanaide, ${ }^{3}$ and Akira Takeshita ${ }^{1}$ \\ ${ }^{1}$ Department of Cardiovascular Medicine, Kyushu University Graduate School of Medical Sciences, Fukuoka, Japan \\ ${ }^{2}$ Surgical Center, Saga Medical School, Saga, Japan \\ ${ }^{3}$ Department of Molecular Cardiology, Kyushu University Graduate School of Medical Sciences, Fukuoka, Japan \\ Address correspondence to: Hiroaki Shimokawa, Department of Cardiovascular Medicine, \\ Kyushu University Graduate School of Medical Sciences, Fukuoka 812-8582, Japan. \\ Phone: 81-92-642-5360; Fax: 81-92-642-5374; E-mail: shimo@cardiol.med.kyushu-u.ac.jp.
}

Received for publication June 5, 2000, and accepted in revised form November 9, 2000.

The endothelium plays an important role in maintaining vascular homeostasis by synthesizing and releasing several endothelium-derived relaxing factors, such as prostacyclin, nitric oxide (NO), and the previously unidentified endothelium-derived hyperpolarizing factor (EDHF). In this study, we examined our hypothesis that hydrogen peroxide $\left(\mathrm{H}_{2} \mathrm{O}_{2}\right)$ derived from endothelial NO synthase (eNOS) is an EDHF. EDHF-mediated relaxation and hyperpolarization in response to acetylcholine (ACh) were markedly attenuated in small mesenteric arteries from eNOS knockout (eNOS-KO) mice. In the eNOS-KO mice, vasodilating and hyperpolarizing responses of vascular smooth muscle per se were fairly well preserved, as was the increase in intracellular calcium in endothelial cells in response to ACh. Antihypertensive treatment with hydralazine failed to improve the EDHF-mediated relaxation. Catalase, which dismutates $\mathrm{H}_{2} \mathrm{O}_{2}$ to form water and oxygen, inhibited EDHF-mediated relaxation and hyperpolarization, but it did not affect endothelium-independent relaxation following treatment with the $\mathrm{K}^{+}$channel opener levcromakalim. Exogenous $\mathrm{H}_{2} \mathrm{O}_{2}$ elicited similar relaxation and hyperpolarization in endothelium-stripped arteries. Finally, laser confocal microscopic examination with peroxide-sensitive fluorescence dye demonstrated that the endothelium produced $\mathrm{H}_{2} \mathrm{O}_{2}$ upon stimulation by $\mathrm{ACh}$ and that the $\mathrm{H}_{2} \mathrm{O}_{2}$ production was markedly reduced in eNOS-KO mice. These results indicate that $\mathrm{H}_{2} \mathrm{O}_{2}$ is an EDHF in mouse small mesenteric arteries and that eNOS is a major source of the reactive oxygen species.

J. Clin. Invest. 106:1521-1530 (2000).

\section{Introduction}

It is widely accepted that endothelium-derived hyperpolarizing factor (EDHF) plays an important role in modulating vasomotor tone, especially in microvessels (1-3). Although more than ten years have passed since the first reports on the existence of $\operatorname{EDHF}(4,5)$, its nature still remains to be identified. In porcine and bovine coronary arteries, epoxyeicosatrienoic acids (EETs), metabolites of cytochrome P-450 monooxygenase, were suggested to be EDHFs (6-8); however, consensus has not been achieved yet $(9-11)$. In rat hepatic arteries, $\mathrm{K}^{+}$released from the endothelium was also suggested to be an EDHF (12); however, this may not be the case in most other blood vessels $(13,14)$. In some arteries, it has been recently suggested that gap junctions may also play a role to cause vasodilatation and hyperpolarization of the underlying vascular smooth muscle $(15,16)$. Thus, more than one EDHF appears to exist, and the contribution of each EDHF to endothelium-dependent relaxation may vary depending on the species tested and the vessels used (1-3).

While EDHF is clearly distinct from NO, previous experimental and clinical studies suggested that these two factors share some biological similarities. First, both
$\mathrm{NO}$ and EDHF are synthesized by endothelial cells in a $\mathrm{Ca}^{2+} /$ calmodulin-dependent manner (17). Second, in situations where NO-mediated relaxation is reduced (e.g., hypertension and hyperlipidemia), EDHF compensates for NO to cause endothelium-dependent relaxation, while in advanced atherosclerosis, EDHF-mediated relaxation is also impaired $(2,3)$. Third, correction of the underlying risk factors improves the relaxation mediated by EDHF as well as that mediated by $\mathrm{NO}(2,3)$. Based on these observations, we hypothesized that a non-NO factor derived from endothelial NO synthase (eNOS), possibly a reactive oxygen species, may be an EDHF.

Indeed, it has been demonstrated that activated eNOS can generate superoxide anions under the depletion of tetrahydrobiopterin or L-arginine in the presence of L-arginine analogues (18). Production of superoxide anions leads to formation of hydrogen peroxide $\left(\mathrm{H}_{2} \mathrm{O}_{2}\right)$ in the vascular endothelium via superoxide dismutase (SOD). Vasoactive properties of reactive oxygen species have been previously described by Rubanyi and Vanhoutte in 1986 (19). Furthermore, $\mathrm{H}_{2} \mathrm{O}_{2}$ has been shown to elicit both hyperpolarization and relaxation in porcine coronary arteries without endothelium (20) and to activate $\mathrm{Ca}^{2+}$-activated $\mathrm{K}^{+}\left(\mathrm{K}_{\mathrm{Ca}}\right)$ channels on vas- 
cular smooth muscle $(21,22)$. In this study, we thus tested our hypothesis that $\mathrm{H}_{2} \mathrm{O}_{2}$ is an EDHF and also examined a possible role of eNOS as a major source of the reactive oxygen species, using control and eNOS knockout (eNOS-KO) mice (23).

\section{Methods}

This study was reviewed by the Committee on Ethics in Animal Experiments of the Kyushu University and was carried out according to the Guidelines for Animal Experiments of the Kyushu University and of the Japanese government.

Animals and tissue preparation. Male eNOS-KO mice and C57BL/6 mice, 10-16 weeks of age, were used. The eNOS-KO mice were originally provided by P. Huang and M. Fishman (Harvard Medical School, Boston, Massachusetts, USA) (23) and maintained in the Laboratory of Animal Experiments in the Kyushu University. The eNOS-KO mice were derived from a cross between SV129J and C57BL/6 mice and were backcrossed to $\mathrm{C} 57 \mathrm{BL} / 6$ mice over ten generations. Thus, C57BL/ 6 mice were used as a wild-type control; they were also maintained in the Laboratory of Animal Experiments in the Kyushu University. Some eNOS-KO mice were treated with hydralazine in order to examine the effect of mildly elevated blood pressure on the EDHF-mediated responses. The treatment with hydralazine hydrochloride $(20 \mathrm{mg} / \mathrm{kg} / \mathrm{d})$ was performed for 6 weeks from 10-16 weeks of age. Systolic blood pressure was measured by tail-cuff method under conscious conditions before the animals were killed. The aorta and small mesenteric arteries (200-240 $\mu \mathrm{m}$ in diameter) were excised and cut into rings for the measurements of both isometric tensions and membrane potentials. The aortic valvular leaflets were excised for fura-2 experiments in which intracellular $\mathrm{Ca}^{2+}$ levels in endothelial cells were measured. To examine endothelium-independent responses, some arterial rings were stripped of the endothelium by gently rubbing the inner surface with a cotton string $(24,25)$.

Organ chamber experiments. Experiments were performed in $37^{\circ} \mathrm{C}$ Krebs solution bubbled with $95 \% \mathrm{O}_{2}$ and $5 \% \mathrm{CO}_{2}$. Isometric tension was recorded in isolated arterial rings precontracted with prostaglandin $\mathrm{F}_{2 \alpha}$ $\left(\mathrm{PGF}_{2 \alpha}\right)(3-10 \mu \mathrm{M})$ or $\mathrm{KCl}(20-60 \mathrm{mM})$. The extent of precontraction was adjusted to $50-70 \%$ of the contractions induced by $62 \mathrm{mM} \mathrm{KCl}(24,25)$. Endotheliumdependent relaxation to $\mathrm{ACh}$ and endothelium-independent relaxation to levcromakalim, sodium nitroprusside (SNP), or $\mathrm{H}_{2} \mathrm{O}_{2}$ were examined. The contribution of vasodilator prostaglandins, $\mathrm{NO}$, and $\mathrm{EDHF}$ to ACh-induced endothelium-dependent relaxation was determined by the inhibitory effect of indomethacin (10 $\mu \mathrm{M}), \mathrm{N}^{\omega}$-nitro-L-arginine (L-NNA, $100 \mu \mathrm{M}$ ), and $\mathrm{KCl}$ (20-60 mM), respectively $(24,25)$. The concentration of indomethacin was sufficient to inhibit the production of vasodilator prostaglandins, as evidenced by the fact that additional application of tranylcypromine (100 $\mu \mathrm{M})$, an inhibitor of prostacyclin synthase, had no fur- ther inhibitory effect on the indomethacin-resistant relaxation (data not shown). The concentration of LNNA was sufficient to inhibit endothelial NO production, as evidenced by the fact that additional application of carboxy-PTIO (5 mM), a potent scavenger of $\mathrm{NO}$, had no further inhibitory effect on the L-NNA-resistant relaxation (data not shown).

To determine the nature of EDHF and the mechanism of EDHF-mediated relaxation, additional experiments were performed in small mesenteric arteries, where EDHF plays a primary role to cause endotheliumdependent relaxation $(24,25)$. The following inhibitors were used: apamin $(1 \mu \mathrm{M}$, an inhibitor of small conductance $\mathrm{K}_{\mathrm{Ca}}$ channels), charybdotoxin (CTx, $100 \mathrm{nM}$, an inhibitor of large and intermediate conductance $\mathrm{K}_{\mathrm{Ca}}$ channels), tetrabutyl-ammonium (TBA, $1 \mathrm{mM}$, a nonspecific inhibitor of $\mathrm{K}_{\mathrm{Ca}}$ channels), catalase $(1250 \mathrm{U} / \mathrm{ml}$, an enzyme which dismutates $\mathrm{H}_{2} \mathrm{O}_{2}$ to form water and oxygen), 3-amino-1,2,4-triazole (amino-triazole, $50 \mathrm{mM}$, an inhibitor of catalase), deferoxamine (1 $\mathrm{mM}$, an inhibitor of Fenton reaction-dependent formation of hydroxyl radical), 17-octadecynoic acid (17-ODYA, 3 $\mu \mathrm{M}$, a suicide substrate inhibitor of cytochrome P-450 monooxygenase) $(9,10), 18 \beta$-glycyrrhetinic acid $(18 \beta$ $\mathrm{GA}, 40 \mu \mathrm{M}$, an inhibitor of gap junctions) (15), ouabain ( $1 \mathrm{mM}$, an inhibitor of $\mathrm{Na} / \mathrm{K}$ pump), and barium (30 $\mu \mathrm{M}$, an inhibitor of inward rectifier $\mathrm{K}^{+}$channels) (12).

Electrophysiological experiments. Electrophysiological experiments were performed in small mesenteric arteries, in which existence of EDHF-mediated responses was confirmed by organ chamber experiments. The rings of small mesenteric arteries from both strains were placed in experimental chambers perfused with $37^{\circ} \mathrm{C}$ Krebs solution containing indomethacin $(10 \mu \mathrm{M})$ and L-NNA $(100 \mu \mathrm{M})$ bubbled with $95 \% \mathrm{O}_{2}$ and $5 \%$ $\mathrm{CO}_{2}$. A fine glass capillary microelectrode was impaled into the smooth muscle cell from the adventitial side. Changes in membrane potentials produced by ACh or exogenous $\mathrm{H}_{2} \mathrm{O}_{2}$ were continuously recorded $(24,25)$.

In situ measurement of intracellular $\mathrm{Ca}^{2+}$ levels in endothelial cells. Endothelial cells on aortic valvular leaflets were used in order to exclude fluorescence signals from the smooth muscle cells (26). Aortic valvular tissue was loaded with acetoxymethyl esters of fura-2 (fura2/AM), a fluorescence $\mathrm{Ca}^{2+}$ indicator dye, for $90 \mathrm{~min}$ utes at $37^{\circ} \mathrm{C}(26,27)$. Fura-2 microfluorometry was performed using a fluorescent microscope (TMD 56; Nikon Co., Tokyo, Japan) equipped with a spectrophotometer (CAM 200; Japan Spectroscope Co., Tokyo, Japan) (27). Fluorescence intensities at 348 and $380 \mathrm{~nm}$ excitation were measured at $500 \mathrm{~nm}$, and their ratio (F348/F380) was recorded at $25^{\circ} \mathrm{C}$. The changes in F348/F380 upon stimulation by ACh were expressed in percent, assuming the value obtained with normal Krebs solution and the maximal value in the presence of cyclopiazonic acid (CPA, $3 \mu \mathrm{M}$, an inhibitor of $\mathrm{Ca}^{2+}$ pump adenosine triphosphatase of the endoplasmic reticulum) and ionomycin ( $25 \mu \mathrm{M}, \mathrm{Ca}^{2+}$ ionophore) to be $0 \%$ and $100 \%$, respectively. 
Detection of $\mathrm{H}_{2} \mathrm{O}_{2}$ production from endothelial cells. Small mesenteric arteries of control and eNOS-KO mice were cut into rings and then opened longitudinally. The vascular strip was loaded with $5 \mu \mathrm{M}$ dichlorodihydrofluorescein diacetate $(\mathrm{DCF})$, a peroxide-sensitive fluorescence dye (28), for 10 minutes, then placed on a slide glass and observed using a laser confocal microscope (LSM-GB200; Olympus Optical Co., Tokyo, Japan) at an excitation wavelength of $488 \mathrm{~nm}$ and an emission wavelength of $520 \mathrm{~nm}$ at $25^{\circ} \mathrm{C}$. Fluorescence images of the endothelium were obtained before and 3 minutes after the application of ACh, which was achieved by dropping $5 \mu \mathrm{l}$ HEPES buffer containing $10 \mu \mathrm{M}$ ACh onto the slide glass using a micropipette. Relative fluorescence intensity was calculated using images obtained under basal conditions without ACh. The inhibitory effect of the pretreatment with indomethacin $(10 \mu \mathrm{M})$, L-NNA $(100 \mu \mathrm{M})$, catalase $(1250 \mathrm{U} / \mathrm{ml})$, or calmodulin antagonists calmidazolium $(10 \mu \mathrm{M})$ and fendiline $(100 \mu \mathrm{M})(17)$ on the ACh-induced increase in fluorescence intensities was determined.

Drugs and solution. The ionic $\mathrm{mM}$ composition of Krebs solution was as follows: $\mathrm{Na}^{+} 144, \mathrm{~K}^{+} 5.9, \mathrm{Mg}^{2+} 1.2, \mathrm{Ca}^{2+}$ 2.5, $\mathrm{H}_{2} \mathrm{PO}_{4}^{-} 1.2, \mathrm{HCO}_{3}^{-} 24, \mathrm{Cl}^{-} 129.7$, glucose 5.5; and that of HEPES buffer was as follows: $\mathrm{Na}^{+} 143, \mathrm{~K}^{+} 5.9$, $\mathrm{Mg}^{2+} 1.2, \mathrm{Ca}^{2+} 1.6, \mathrm{H}_{2} \mathrm{PO}_{4}^{-} 1.2, \mathrm{Cl}^{-} 150.9$, glucose 11 , HEPES 5. ACh, indomethacin, L-NNA, catalase (catalog no. C-9322), SNP, 18 $\beta$-GA, 17-ODYA, apamin, CTx, TBA, barium chloride, ouabain, hydralazine hydrochloride, $\mathrm{CPA}$, ionomycin, calmidazolium, and fendiline were obtained from Sigma Chemical Co. (St. Louis, Missouri, USA). DCF and fura-2/AM were obtained from Molecular Probes Inc. (Eugene, Oregon, USA). Levcromakalim was a kind gift from SmithKline Beecham Pharmaceuticals (Philadelphia, Pennsylvania, USA). Indomethacin was dissolved in $10 \mathrm{mM} \mathrm{Na}_{2} \mathrm{CO}_{3}$. 18 $\beta$-GA, 17-ODYA, DCF, fura-2/AM, ionomycin, calmidazolium, and fendiline were dissolved in DMSO. Levcromakalim was dissolved in 90\% ethanol, and other drugs were dissolved in distilled water. The solvent used did not affect the mechanical or electrical responses at their final bath concentrations. The amount of endotoxin contaminated in the catalase compound, which was determined by synthetic chromogenic substrate method (SRL Inc., Tokyo, Japan), was $24 \mathrm{ng} / \mathrm{ml}$ at final bath concentration.

Statistical analysis. Data are shown as mean \pm SEM. Dose-response curves were analyzed by two-way ANOVA followed by Scheffe's post-hoc test for multiple comparisons. Other variables were analyzed by paired Student's t-test or one-way ANOVA followed by Fisher's post-hoc test for multiple comparisons. $P<$ 0.05 was considered to be statistically significant.

\section{Results}

Endothelium-dependent relaxation in control and eNOS-KO mice. In the aortae of control mice, endotheliumdependent relaxation to $\mathrm{ACh}$ was unaffected by indomethacin but was almost abolished by L-NNA, indicating that $\mathrm{NO}$ mainly mediates the relaxations to $\mathrm{ACh}$ in the aorta (Figure 1a). By contrast, in small mesenteric arteries, endothelium-dependent relaxation to ACh was resistant to indomethacin and L-NNA but was highly sensitive to $\mathrm{KCl}$ (Figure $1 \mathrm{a}$ ). In the aortae from eNOS-KO mice, endothelium-dependent relaxation to ACh was almost absent (Figure 1b). In small mesenteric arteries from eNOS-KO mice, indomethacin partially inhibited the ACh-induced relaxation, whereas L-NNA did not alter indomethacin-resistant relaxation, indicating an absence of NO-mediated relaxation. Importantly, EDHF-mediated relaxation (observed in the presence of indomethacin and L-NNA) was also markedly reduced in eNOS-KO mice as compared with control mice (Figure 1b).
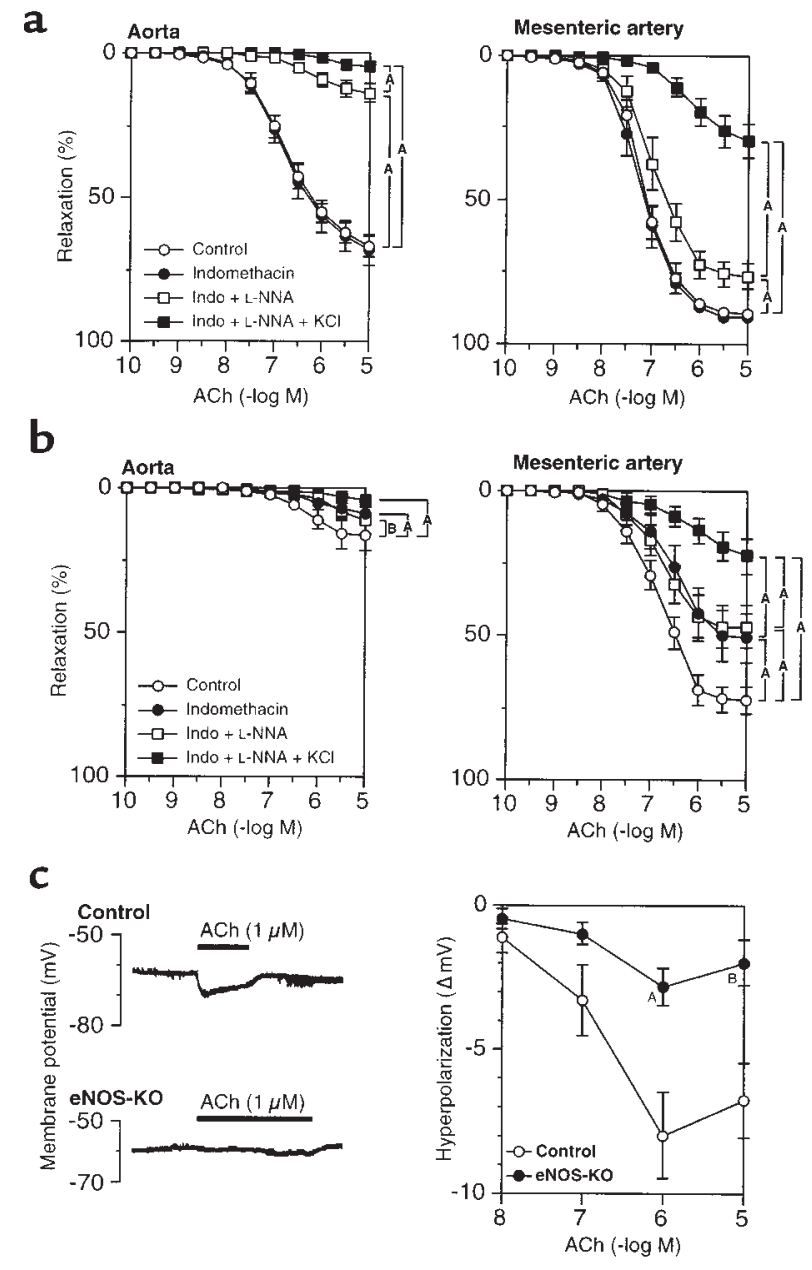

Figure 1

Reduced EDHF-mediated endothelium-dependent relaxation and hyperpolarization in eNOS-KO mice. (a) Endothelium-dependent relaxation to ACh of the aorta (left, $n=11$ ) and of small mesenteric arteries (right, $n=9$ ) in control mice. NO plays a primary role in the aorta, whereas EDHF plays a primary role in small mesenteric arteries. ${ }^{A} P<$ $0.01,{ }^{B} P<0.05$. (b) Endothelium-dependent relaxation to ACh of the aorta (left) and of small mesenteric arteries (right, $n=10$ each) in eNOS-KO mice. The relaxation was absent in the aorta, whereas in small mesenteric arteries those responses were partially compensated by vasodilator prostaglandins with a marked reduction of EDHF-mediated responses. ${ }^{A} P<0.01,{ }^{B} P<0.05$. (c) Endothelium-dependent hyperpolarization to $A C h$ was also markedly reduced in small mesenteric arteries of eNOS-KO mice $(n=5-6) .{ }^{A} P<0.01,{ }^{\mathrm{B}} P<0.05$ vs. control. 
Endothelium-dependent byperpolarization in control and eNOS-KO mice. Resting membrane potentials of smooth muscle cells from small mesenteric arteries were significantly less negative in eNOS-KO than in control mice $(-60.2 \pm 0.4 \mathrm{mV}$ vs. $-63.1 \pm 0.6 \mathrm{mV}, P<0.01, n=7$ each $)$.

a
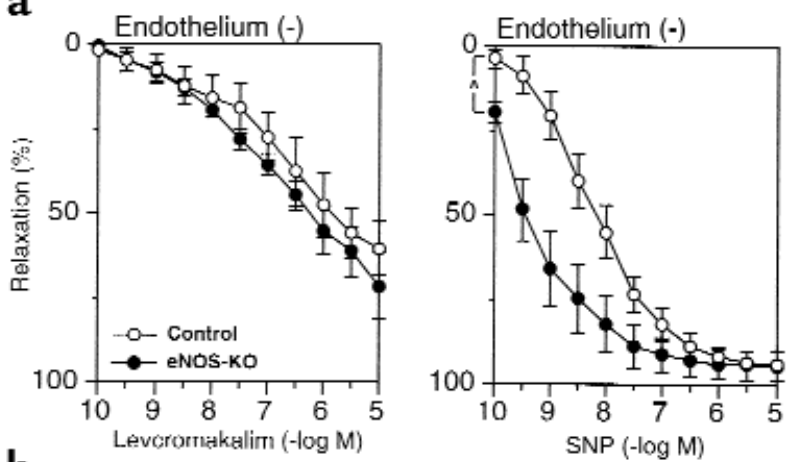

b
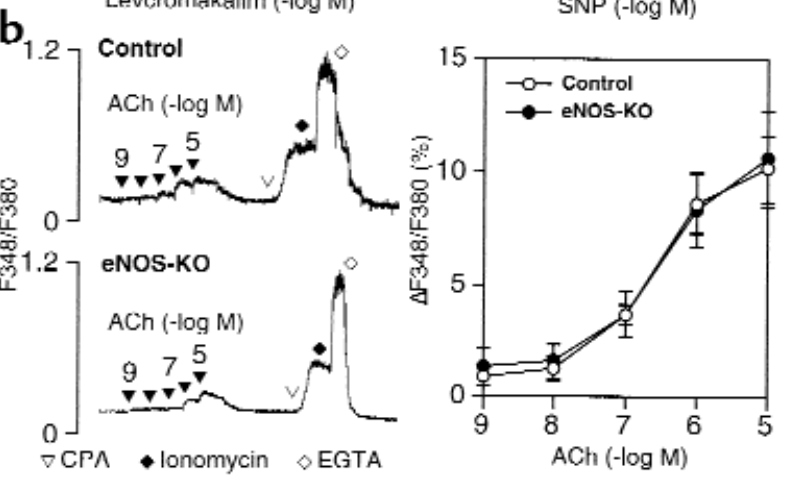

C
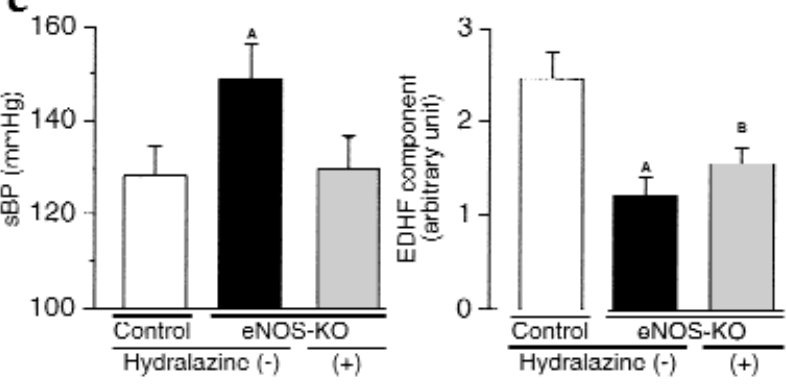

Figure 2

Preserved endothelium-independent relaxation and increase in intracellular $\mathrm{Ca}^{2+}$ levels upon stimulation by agonists, and a failure of antihypertensive therapy to improve the reduced EDHF-mediated responses in eNOS-KO mice. (a) Endothelium-independent relaxation in small mesenteric arteries to levcromakalim was preserved (left, $n=6$ each) while those to SNP were enhanced (right, $n=5-6$ ) in eNOS-KO mice. ${ }^{A} P<0.01$. (b) Direct measurement of the changes in intracellular $\mathrm{Ca}^{2+}$ levels in endothelial cells. ACh $(1 \mathrm{nM}-10 \mu \mathrm{M}), \mathrm{CPA}(3 \mu \mathrm{M})$, and ionomycin $(25 \mu \mathrm{M})$ caused an increase, while EGTA $(2 \mathrm{mM})$ caused a decrease in intracellular $\mathrm{Ca}^{2+}$ levels as shown by F348/F380 (left). The increase in intracellular $\mathrm{Ca}^{2+}$ levels, when normalized to ionomycininduced maximal F348/F380, were comparable between the two strains (right, $n=5$ each). (c) Although the antihypertensive therapy with hydralazine for 6 weeks normalized blood pressure in eNOS-KO mice (left), the treatment failed to improve the reduced EDHF-mediated responses $(\mathrm{KCl}$-sensitive component after the blockade of cyclooxygenase with $10 \mu \mathrm{M}$ indomethacin and the blockade of eNOS with $100 \mu \mathrm{M} \mathrm{L-NNA}$ ) in eNOS-KO mice (right, $n=8-10$ ). ${ }^{A} P<0.01$, ${ }^{\mathrm{B}} P$ $<0.05$ vs. control. sBP, systolic blood pressure.
Treatment with L-NNA had no significant effect on the resting membrane potentials (data not shown). ACh (10 $\mathrm{nM}-10 \mu \mathrm{M})$ concentration-dependently elicited hyperpolarization of blood vessels with intact endothelium in control mice (Figure 1c). In eNOS-KO mice, the extent of the hyperpolarization to ACh was again markedly reduced (Figure 1c).

Endothelium-independent relaxation in control and eNOS$K O$ mice. Levcromakalim, which opens ATP-sensitive $\mathrm{K}^{+}$ channels, and SNP, an NO donor, elicited relaxation in endothelium-stripped small mesenteric arteries of mice (Figure 2a). Endothelium-independent relaxation to levcromakalim was comparable between the two strains, whereas endothelium-independent relaxation to SNP was rather significantly enhanced in eNOS-KO mice (Figure 2a).

Intracellular $\mathrm{Ca}^{2+}$ responses to ACh in endothelial cells. Intracellular $\mathrm{Ca}^{2+}$ responses to ACh were recorded in fura2 -loaded endothelial cells on the aortic valves in order to exclude fluorescence signals from smooth muscle cells. Although EDHF-mediated responses are mainly observed in mesenteric arteries, it is appropriate to examine $\mathrm{Ca}^{2+}$ signals in aortic endothelial cells, since they also respond to $\mathrm{ACh}$ to cause $\mathrm{NO}$ production in a $\mathrm{Ca}^{2+}$-dependent manner. ACh $(1 \mathrm{nM}-10 \mu \mathrm{M})$ concentration-dependently increased intracellular $\mathrm{Ca}^{2+}$ levels in the endothelium of control and eNOS-KO mice (Figure $2 \mathrm{~b}$ ). Maximal intracellular $\mathrm{Ca}^{2+}$ response was recorded after the addition of CPA (an inhibitor of $\mathrm{Ca}^{2+}$ pump adenosinetriphosphatase of the endoplasmic reticulum, $3 \mu \mathrm{M})$ and ionomycin $\left(\mathrm{Ca}^{2+}\right.$ ionophore, $\left.25 \mu \mathrm{M}\right)$. The extent of intracellular $\mathrm{Ca}^{2+}$ response, normalized to the maximal response to CPA plus ionomycin, was comparable between the two strains (Figure $2 b$ ).

Effect of antibypertensive treatment on EDHF-mediated relaxation in eNOS-KO mice. Mild hypertension was observed in eNOS-KO mice (Figure 2c). Antihypertensive treatment with oral hydralazine hydrochloride for 6 weeks effectively lowered blood pressure in eNOS-KO mice (Figure 2c). However, the antihypertensive treatment with hydralazine failed to improve the EDHF-mediated component in the ACh-induced relaxation (KCl-sensitive component in the presence of indomethacin and L-NNA) in eNOS-KO mice (Figure 2c).

Effects of $\mathrm{K}^{+}$channel inbibitors on the EDHF-mediated responses. The combination of apamin $(1 \mu \mathrm{M})$ and CTx (100 nM), inhibitors of $\mathrm{K}_{\mathrm{Ca}}$ channels, significantly inhibited the EDHF-mediated relaxation in small mesenteric arteries of control mice (Table 1). Pretreatment with TBA $(1 \mathrm{mM})$, a nonspecific inhibitor of $\mathrm{K}_{\mathrm{Ca}}$ channels, caused a slight $(<30 \%)$ increase in basal tension in most arteries (five out of six arteries, data not shown). TBA almost abolished the EDHF-mediated relaxation in control mice (Table 1 ). Identical results were obtained using eNOS-KO mice (data not shown).

Nature of EDHF in small mesenteric arteries of mice. The contribution of $\mathrm{H}_{2} \mathrm{O}_{2}$ in the EDHF-mediated relaxation was examined by the inhibitory effect of catalase, an enzyme that dismutates $\mathrm{H}_{2} \mathrm{O}_{2}$ to form water 
and oxygen. In control mice, catalase $(1250 \mathrm{U} / \mathrm{ml})$ only slightly inhibited the relaxation in the presence of indomethacin alone; however, in the presence of both indomethacin and L-NNA, catalase markedly inhibited the relaxation to ACh (Figure 3a). By contrast, catalase, when inactivated at its peroxide-binding site by aminotriazole $(50 \mathrm{mM})(29)$, failed to inhibit ACh-induced relaxation in the presence of indomethacin and L-NNA (Table 1). These results suggest that in the presence of indomethacin and catalase, $\mathrm{NO}$ acts as the principal endothelium-derived relaxing factor (EDRF). However, when the generation of cyclooxygenase-derived products and $\mathrm{NO}$ is inhibited, $\mathrm{H}_{2} \mathrm{O}_{2}$ acts as the primary EDRF. Consistent with this interpretation, in eNOS-KO mice where NO cannot act as an EDRF, catalase in the presence of either indomethacin alone or both indomethacin and LNNA almost completely blocked ACh-dependent relaxation (Figure 3A). Membrane potential recordings demonstrated that catalase also inhibited the ACh-induced endothelium-dependent hyperpolarization in control mice (Figure 3b). By contrast, catalase did not affect the endothelium-independent hyperpolarization (Figure $3 b)$ or relaxation $(n=3$, data not shown) in response to levcromakalim. Deferoxamine $(1 \mathrm{mM})$, an inhibitor of Fenton reaction-dependent formation of hydroxyl radical, had no inhibitory effect on the EDHF-mediated relaxation (Table 1).

17-ODYA (an inhibitor of cytochrome P-450 monooxygenase, $3 \mu \mathrm{M})(9,10)$ or $18 \beta-G A$ (an inhibitor of gap junctional electrical communication, $40 \mu \mathrm{M}$ ) (15) had no inhibitory effect on the EDHF-mediated relaxation in the presence of indomethacin and L-NNA (Table 1), although 18 $\beta$-GA also decreased the sensitivity to $\mathrm{PGF}_{2 \alpha}$ in producing precontraction (data not shown). It was shown that $\mathrm{K}^{+}$released from the endothelium is an EDHF in rat hepatic arteries, causing relaxation and hyperpolarization of the smooth muscle by activating $\mathrm{Na} / \mathrm{K}$ pump and inward rectifier $\mathrm{K}^{+}$channels, and that EDHF-mediated responses were inhibited by the combination of ouabain plus barium, inhibitors of $\mathrm{Na} / \mathrm{K}$ pump and inward rectifier $\mathrm{K}^{+}$channels (12). In this study, treatment with ouabain $(1 \mathrm{mM})$ plus barium $(30 \mu \mathrm{M})$ caused an increase in basal tone associated with oscillations in five out of nine arterial rings studied, making it difficult to analyze endothelium-dependent relaxation (data not shown). In the remaining arteries (in four out of nine rings), endothelium-dependent relaxation was observed and the combination of ouabain plus barium had no inhibitory effect on the EDHF-mediated relaxation (Table 1). Cumulative addition of $\mathrm{KCl}(5-20 \mathrm{mM})$, which may cause hyperpolarization and relaxation (12), did not cause any relaxation $(n=4$, data not shown).

$\mathrm{H}_{2} \mathrm{O}_{2}$-induced relaxation and hyperpolarization. Vasoactive properties of exogenous $\mathrm{H}_{2} \mathrm{O}_{2}$ were examined in endothelium-stripped small mesenteric arteries of control mice. Exogenous $\mathrm{H}_{2} \mathrm{O}_{2}$ dose-dependently elicited relaxation that was sensitive to high $\mathrm{K}^{+}$or TBA but resist- ant to the combination of apamin plus CTx (Figure 3c). Electrophysiological experiments revealed that exogenous $\mathrm{H}_{2} \mathrm{O}_{2}$ also elicited concentration-dependent hyperpolarization of vascular smooth muscle cells in endothelium-stripped small mesenteric arteries (Figure 3c).

$\mathrm{H}_{2} \mathrm{O}_{2}$ production from endothelial cells. $\mathrm{H}_{2} \mathrm{O}_{2}$ production from endothelial cells was detected in the experiments using a laser confocal microscope with DCF, a peroxidesensitive fluorescence dye. In this system the endothelial monolayer was clearly distinguished from underlying

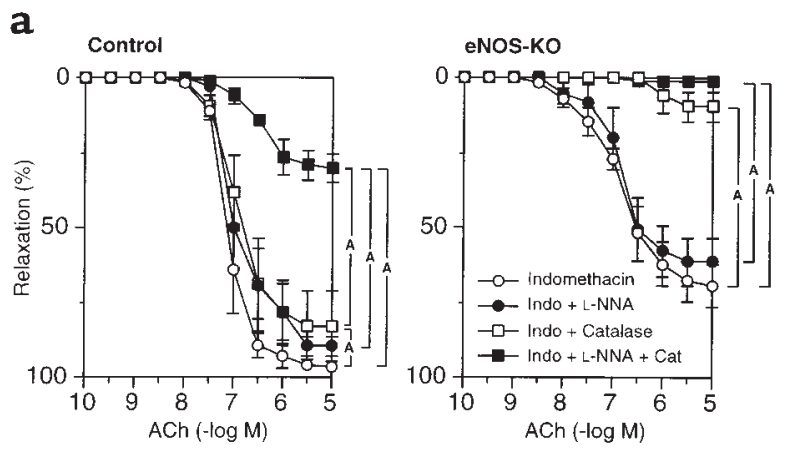

b
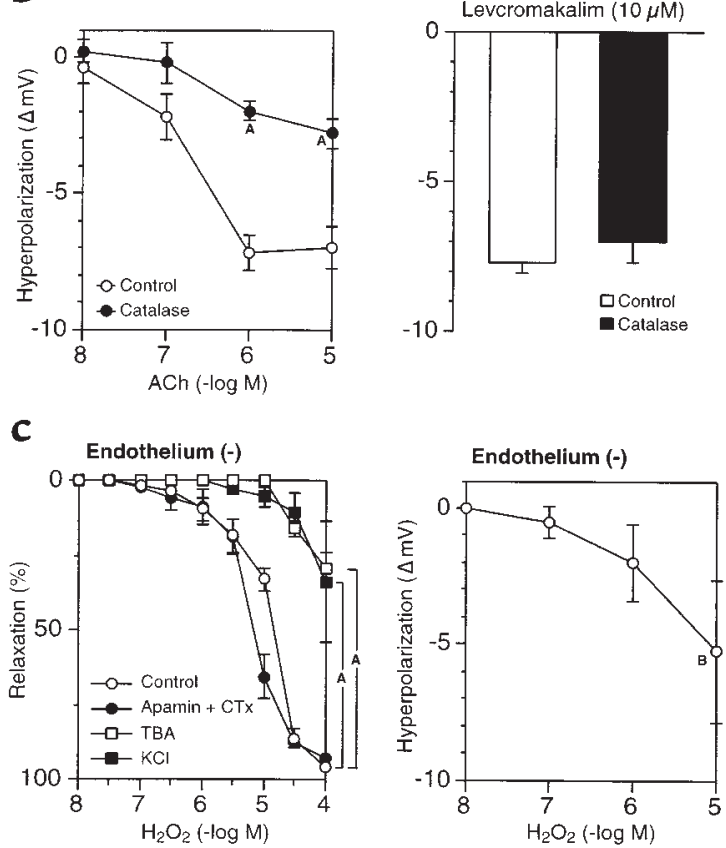

Figure 3

Identification of the nature of EDHF in mouse small mesenteric arteries. (a) Catalase $(1250 \mathrm{U} / \mathrm{ml})$ markedly inhibited the endotheliumdependent relaxation to ACh in control mice (after the blockade of cyclooxygenase and eNOS) (left, $n=5$ ) and in eNOS-KO mice (after the blockade of cyclooxygenase) (right, $n=4$ ). ${ }^{A} P<0.01$. (b) Catalase also inhibited the ACh-induced endothelium-dependent hyperpolarization in small mesenteric arteries of control mice (left, $n=5$ ), whereas it did not affect the levcromakalim-induced $(10 \mu \mathrm{M})$ hyperpolarization (right, $n=3$ ). ${ }^{A} P<0.01$ vs. control. (c) $\mathrm{H}_{2} \mathrm{O}_{2}$, when exogenously applied, caused endothelium-independent relaxation (left, $n=5$ ) as well as hyperpolarization (right, $n=4$ ) in small mesenteric arteries of control mice without endothelium. ${ }^{A} P<0.01$ vs. control, ${ }^{B} P<0.05$ vs. resting membrane potentials. Experiments were performed in the presence of indomethacin $(10 \mu \mathrm{M})$ and L-NNA $(100 \mu \mathrm{M})(\mathbf{b}$ and $\mathbf{c})$. 

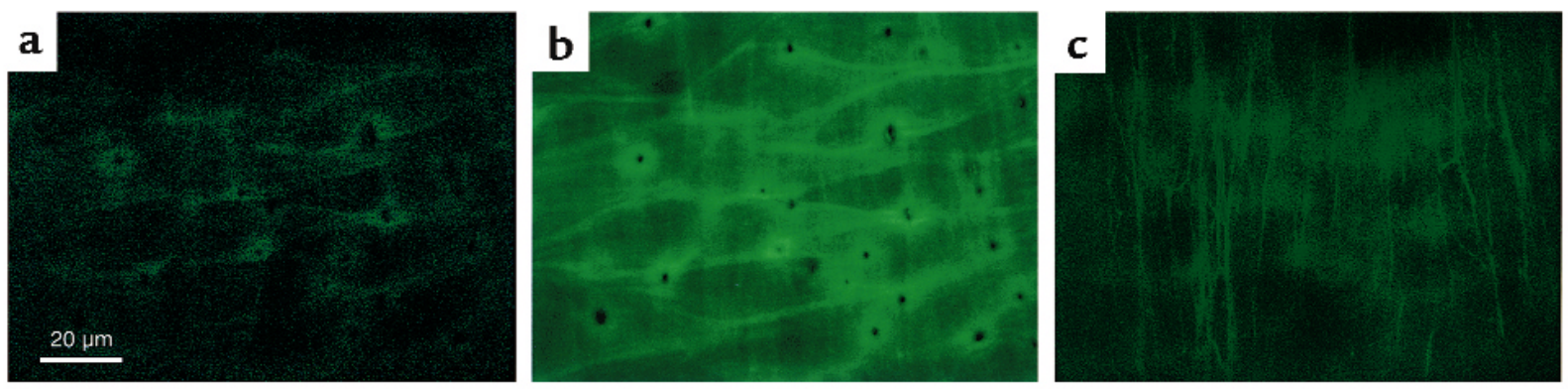

Figure 4

ACh-induced production of $\mathrm{H}_{2} \mathrm{O}_{2}$ by the endothelium detected as an increase in fluorescence intensity in the DCF-loaded endothelial cells in small mesenteric arteries of mice. Fluorescence images of the endothelium in small mesenteric artery of a control mouse were obtained before (a) and 3 minutes after (b, d, and $\mathbf{e})$ the application of ACh $(10 \mu \mathrm{M})$. (c) Fluorescence image of smooth muscle layer of a control mouse obtained at the same visual field as $\mathbf{a}$ and $\mathbf{b}$. The direction and depth of
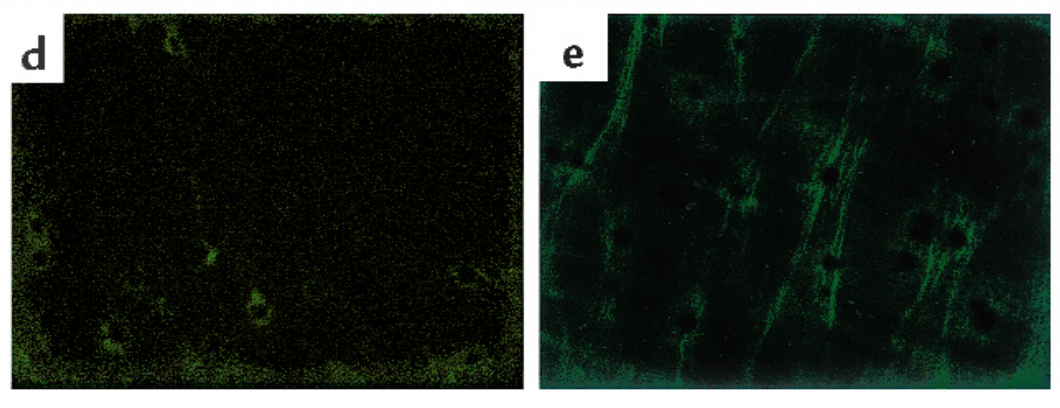
the smooth muscle layer were apparently different from those of the endothelial layer. (d) ACh-induced increase in fluorescence intensity was almost abolished by pretreatment with catalase $(1250 \mathrm{U} / \mathrm{ml})$ in a control mouse. (e) ACh-induced increase in the fluorescence intensity was markedly reduced in an eNOS-KO mouse. All experiments were performed in the presence of indomethacin $(10 \mu \mathrm{M})$ and L-NNA $(100 \mu \mathrm{M})$.

smooth muscle cells (Figure 4, a-c). ACh caused a significant increase in the DCF fluorescence intensity in endothelial cells 3 minutes after the application, especially at the cell membrane (Figure 4 , $a$ and $b$ ). This was unaffected by pretreatment with indomethacin $(10 \mu \mathrm{M})$, L-NNA $(100 \mu \mathrm{M})$, or both (Figure $5 \mathrm{a})$. When the arterial strip was pretreated with catalase $(1250 \mathrm{U} / \mathrm{ml})$, the AChinduced increase in the fluorescence intensity was almost abolished (Figures $4 d$ and $5 b$ ). The inhibitory effect of catalase was more evident after the treatment with indomethacin and L-NNA (Figure 5b). The extent of ACh-induced increase in the DCF fluorescence intensity was markedly reduced in the endothelium from eNOSKO mice (Figures $4 \mathrm{e}$ and $5 \mathrm{c}$ ). Calmidazolium $(10 \mu \mathrm{M})$ or fendiline $(100 \mu \mathrm{M})$, structurally different calmodulin antagonists, significantly inhibited the ACh-induced increase in the DCF fluorescence intensity (Figure 5d).

\section{Discussion}

Endothelium-dependent relaxation and hyperpolarization in control and eNOS-KO mice. Endothelium-dependent relaxation to ACh was mainly mediated by EDHF in small mesenteric arteries from control mice, whereas that in the aorta was mainly mediated by $\mathrm{NO}$, a finding consistent with our previous observations in rats (24) and humans $(3,25)$. Although it was reported that EDHF activity was absent in the main trunk of mouse mesenteric arteries (30), we were able to consistently document EDHF-mediated hyperpolarization and relaxation in the second order of the artery (200-240 $\mu \mathrm{m}$ in diameter). The discrepancy may be due to the

difference in vessel size studied. In eNOS-KO mice, where NO-mediated relaxation was absent, vasodilator prostaglandins were upregulated and partially compensated endothelium-dependent relaxation, a finding consistent with the previous reports $(30,31)$. EDHFmediated relaxation and hyperpolarization, which might be enhanced in the absence of $\mathrm{NO}(32,33)$, were also markedly reduced in eNOS-KO mice.

The reduced EDHF-mediated responses in eNOS-KO mice could be caused by mechanisms other than reduced production of the factor. First, properties of vascular smooth muscle might be altered in eNOS-KO mice. However, in eNOS-KO mice, endothelium-independent relaxation to levcromakalim was preserved and endothelium-independent relaxation to SNP was rather enhanced, a finding consistent with a previous report (34). The slightly depolarized resting membrane potentials of smooth muscle cells do not explain the reduced ACh-induced hyperpolarization in eNOS-KO mice, because depolarized cells generally tend to hyperpolarize more upon opening of $\mathrm{K}^{+}$channels. Second, since EDHF is produced by the endothelium in a $\mathrm{Ca}^{2+} /$ calmodulin-dependent manner (17), the reduced EDHF-mediated responses to ACh in eNOS-KO mice might be a result of reduced endothelial intracellular $\mathrm{Ca}^{2+}$ response to ACh. However, intracellular $\mathrm{Ca}^{2+}$ responses to $\mathrm{ACh}$, recorded in the fura-2-loaded endothelial cells, were comparable between the two strains. Third, the reduced EDHF-mediated responses in eNOS-KO mice might be a result of the elevated blood pressure (35). However, this may not be the case, since antihypertensive treatment with hydralazine failed to improve the EDHF-mediated relaxation. Therefore, in eNOS-KO mice, endothelial production of EDHF per se is reduced in association with eNOS deficiency. Thus, the above-mentioned results support our hypothesis that eNOS may be one of the sources of EDHF.

$\mathrm{H}_{2} \mathrm{O}_{2}$ mediates the EDHF responses in small mesenteric 
arteries of mice. In the present study, catalase inhibited ACh-induced endothelium-dependent relaxation and hyperpolarization attributed to EDHF. Catalase compound may often be contaminated with endotoxin (29) or other substances such as thymol and SOD, which might alter endothelium-dependent vasodilatation (36). However, catalase did not alter NO-mediated relaxation nor levcromakalim-induced relaxation (data not shown) and hyperpolarization, excluding a possibility of its nonspecific effects on endothelial or smooth muscle functions by contaminated substances. Furthermore, catalase, when inactivated at its peroxide-binding site by aminotriazole (29), lost its inhibitory effect on the EDHF-mediated relaxation. These results indicate that the inhibitory effects of catalase on the EDHF-mediated responses were indeed mediated by its enzymatic effect on $\mathrm{H}_{2} \mathrm{O}_{2}$. Thus, $\mathrm{H}_{2} \mathrm{O}_{2}$ appears to mediate the EDHF responses in small mesenteric arteries of mice.

It has been proposed that EETs, products of cytochrome P-450 monooxygenase, may be an EDHF in some vascular beds, including porcine and bovine coronary arteries (6-8) and mouse gracilis muscle arterioles (37). In our study, however, 17-ODYA, a specific inhibitor of cytochrome P-450 monooxygenase $(9,10)$, had no inhibitory effect on the EDHF-mediated relaxation, which thus excluded this possibility. It has also been proposed that intercellular electrical communication between endothelial cells and vascular smooth muscle cells through gap junctions could contribute to endothelium-dependent relaxation in other blood vessels, including mouse hindlimb arteries $(15,16,38)$. However, this mechanism may not play a central role in mouse small mesenteric arteries, since gap junction inhibitor 18ß-GA (15) had no significant inhibitory effect on the EDHF-mediated relaxation. It was also shown that $\mathrm{K}^{+}$released from the endothelium is an EDHF in rat hepatic arteries, causing relaxation and hyperpolarization of the smooth muscle by activating $\mathrm{Na} / \mathrm{K}$ pump and inward rectifier $\mathrm{K}^{+}$channels (12). In this study, however, the combination of ouabain plus barium failed to inhibit the EDHF-mediated relaxation, and cumulative addition of $\mathrm{KCl}$ did not cause any relaxation. Thus, the possibility that $\mathrm{K}^{+}$is an EDHF may also be less likely in mouse mesenteric arteries. These results suggest that different mechanisms may be involved in the EDHF-mediated responses in different vascular beds even within the mouse. However, it should be noted that these studies have employed different methodologies, including preparation of arteries (in vivo vs. ex vivo, pressurized vs. nonpressurized, and perfused vs. nonperfused) and a method to analyze the EDHF responses (pharmacological vs. electrophysiological).

$\mathrm{H}_{2} \mathrm{O}_{2}$ production and its sources in endothelial cells. Vascular endothelial cells have a capacity to produce superoxide anions and $\mathrm{H}_{2} \mathrm{O}_{2}$ from several intracellular sources, including eNOS, cyclooxygenase, lipoxygenase, $\mathrm{P}-450$ monooxygenase, and $\mathrm{NAD}(\mathrm{P}) \mathrm{H}$ oxidases (39). eNOS-dependent production of superoxide and $\mathrm{H}_{2} \mathrm{O}_{2}$ from the endothelium in situ has been previously

\section{Table 1}

Pharmacological characteristics of ACh-induced EDHF-mediated relaxation in small mesenteric arteries of control mice, and effect of $\mathrm{K}^{+}$channel blockers and other inhibitors

\begin{tabular}{|c|c|c|c|c|}
\hline \multirow[t]{2}{*}{ Inhibitor(s) } & \multicolumn{2}{|c|}{ Absent } & \multicolumn{2}{|c|}{ Present } \\
\hline & $\mathrm{EC}_{50}$ & Max & $\mathrm{EC}_{50}$ & Max \\
\hline \multicolumn{5}{|l|}{$\mathrm{K}^{+}$channel blockers } \\
\hline $\begin{array}{l}\text { Apamin + CTx } \\
\text { TBA }\end{array}$ & $\begin{array}{l}6.9 \pm 0.2 \\
7.1 \pm 0.2\end{array}$ & $\begin{array}{l}77 \pm 8 \\
78 \pm 7\end{array}$ & $\begin{array}{c}6.8 \pm 0.3 \\
\text { ND }\end{array}$ & $\begin{array}{l}48 \pm 8^{A} \\
18 \pm 7^{A}\end{array}$ \\
\hline \multicolumn{5}{|l|}{ Other inhibitors } \\
\hline $\begin{array}{l}\text { Catalase } \\
\text { Inactivated catalase } \\
\text { Deferoxamine } \\
\text { 17-ODYA } \\
\text { 18ß-GA } \\
\text { Ouabain + barium }\end{array}$ & $\begin{array}{l}6.8 \pm 0.3 \\
7.2 \pm 0.1 \\
7.1 \pm 0.2 \\
7.2 \pm 0.2 \\
7.2 \pm 0.2 \\
6.9 \pm 0.2\end{array}$ & $\begin{array}{l}89 \pm 3 \\
90 \pm 4 \\
83 \pm 2 \\
79 \pm 6 \\
81 \pm 5 \\
83 \pm 4\end{array}$ & $\begin{array}{l}6.5 \pm 0.1 \\
7.2 \pm 0.2 \\
7.2 \pm 0.2 \\
7.6 \pm 0.4 \\
7.3 \pm 0.3 \\
7.2 \pm 0.1\end{array}$ & $\begin{array}{l}30 \pm 4^{B} \\
93 \pm 3 \\
80 \pm 2 \\
70 \pm 7 \\
63 \pm 9 \\
77 \pm 6\end{array}$ \\
\hline
\end{tabular}

All experiments were performed in the presence of indomethacin $(10 \mu \mathrm{M})$ and L-NNA $(100 \mu \mathrm{M})$. Data are shown as mean \pm SEM. Inactivated catalase, catalase $(1250 \mathrm{U} / \mathrm{mL})$ inactivated with aminotriazole $(50 \mathrm{mM}) ; \mathrm{EC}_{50}$, negative logarithm of half-maximal effective concentration of ACh; Max, maximal relaxation to ACh (\%); ND, not determined because of abolition of the response. ${ }^{A} P<0.05,{ }^{B} P<0.01$ vs. absent.

reported (40). Since eNOS can generate superoxide in the presence of L-arginine analogues (18), the synthase could serve as a source of superoxide as well as $\mathrm{H}_{2} \mathrm{O}_{2}$ (the dismutation product of superoxide) in the presence of L-NNA. In the present study, we were able to detect endothelial production of $\mathrm{H}_{2} \mathrm{O}_{2}$, which was indeed unaffected by indomethacin or L-NNA and was inhibited by calmodulin antagonists. eNOS appears to be one of the sources of the ACh-induced $\mathrm{H}_{2} \mathrm{O}_{2}$ production from the endothelium, since ACh-induced $\mathrm{H}_{2} \mathrm{O}_{2}$ production was markedly reduced in blood vessels from eNOS-KO mice. As catalase-sensitive EDHF responses and $\mathrm{H}_{2} \mathrm{O}_{2}$ production were still noted in eNOS-KO mice, $\mathrm{H}_{2} \mathrm{O}_{2}$ may also be generated by other oxidases. Although cyclooxygenase-derived $\mathrm{H}_{2} \mathrm{O}_{2}$ was identified as a mediator of bradykinin-induced relaxation in rat cerebral arterioles (41), ACh-induced $\mathrm{H}_{2} \mathrm{O}_{2}$ production was insensitive to the blockade of cyclooxygenase in the present study. Previous studies also examined the possible role of cytochrome P-450-derived $\mathrm{H}_{2} \mathrm{O}_{2}$ as an EDHF in coronary arteries of rats (11) and pigs (42), with negative results. In our study, 17-ODYA had no inhibitory effect on the EDHF-mediated relaxation, excluding a possibility of cytochrome P-450 as a source of EDHF or $\mathrm{H}_{2} \mathrm{O}_{2}$, a finding consistent with a previous study (42). Thus, other sources of $\mathrm{H}_{2} \mathrm{O}_{2}$ in endothelial cells, which may be mediated by a $\mathrm{Ca}^{2+} /$ calmodulin-dependent process, remain to be identified in a future study.

In the present study, ACh caused a significant increase in catalase-sensitive peroxide-dependent fluorescence in the intact endothelium, confirming the production of $\mathrm{H}_{2} \mathrm{O}_{2}$ by the endothelial cells. However, we were unable to estimate the amounts of $\mathrm{H}_{2} \mathrm{O}_{2}$ produced by the endothelium because it was difficult to obtain a concentration-response curve of $\mathrm{H}_{2} \mathrm{O}_{2}$ - 

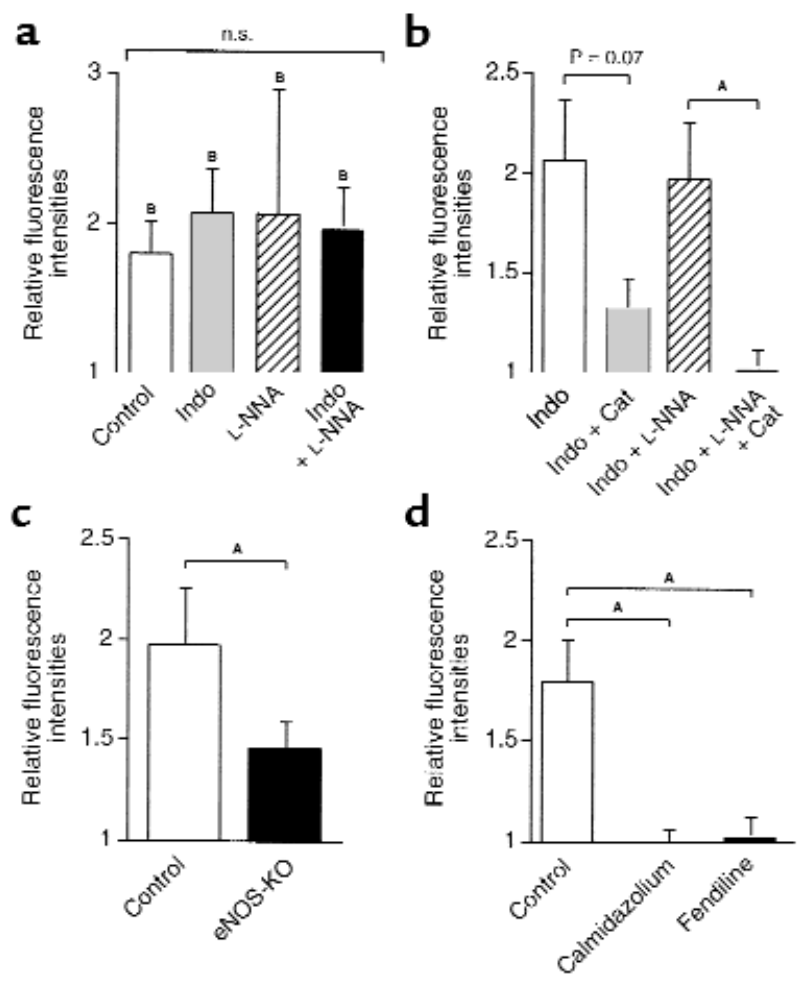

\section{Figure 5}

ACh-induced production of $\mathrm{H}_{2} \mathrm{O}_{2}$ by the endothelium. DCFdependent fluorescence intensities (determined 3 minutes after application of $\mathrm{ACh}$ ) are expressed as fold increase from that under basal conditions. (a) ACh $(10 \mu \mathrm{M})$ caused a significant increase in fluorescence intensity. Pretreatment with indomethacin (10 $\mu \mathrm{M})$, L-NNA $(100 \mu \mathrm{M})$, or both did not affect the responses $(n=$ 5-7). NS, not significant. (b) Inhibitory effect of catalase on the ACh-induced increase in fluorescence intensity $(n=4-7)$. (c) The ACh-induced increase in fluorescence intensity was significantly reduced in eNOS-KO mice $(n=4)$. Experiments were performed in the presence of indomethacin $(10 \mu \mathrm{M})$ and L-NNA $(100 \mu \mathrm{M})$. (d) Inhibitory effect of calmodulin antagonists calmidazolium (10 $\mu \mathrm{M})$ and fendiline $(100 \mu \mathrm{M})$ on the ACh-induced increase in fluorescence intensity $(n=5-6)$. Indo, indomethacin $(10 \mu \mathrm{M})$; Cat, catalase $(1250 \mathrm{U} / \mathrm{ml})$. ${ }^{A} P<0.05$ by one-way ANOVA; ${ }^{B} P<0.05$ vs. basal condition by paired Student's $t$ test.

induced fluorescence for calibration, for the following reasons. First, it was difficult to apply several doses of $\mathrm{H}_{2} \mathrm{O}_{2}$ in a cumulative manner on the same specimen, because ACh or $\mathrm{H}_{2} \mathrm{O}_{2}$ was applied directly onto the slide glasses. Second, repeated scanning by laser itself causes degradation of the fluorescence dye and may affect the fluorescence intensity. The concentration of $\mathrm{H}_{2} \mathrm{O}_{2}$ needed to elicit significant hyperpolarization and relaxation $(10 \mu \mathrm{M})$ was rather high in a physiological situation (40); however, that of $\mathrm{H}_{2} \mathrm{O}_{2}$ needed to act as an EDHF may be overestimated, because exogenous $\mathrm{H}_{2} \mathrm{O}_{2}$ can be rapidly scavenged by endogenous peroxidases when diffusing to smooth muscle cells.

Mechanism of $\mathrm{H}_{2} \mathrm{O}_{2}$-induced hyperpolarization and relaxation. $\mathrm{H}_{2} \mathrm{O}_{2}$ may cause hyperpolarization of vascular smooth muscle by activating $\mathrm{K}_{\mathrm{Ca}}$ channels, both by direct modulation of channels and by a cGMP-dependent mechanism (22) or a lipoxygenase-mediated mechanism $(21,43)$, in porcine coronary arteries. $\mathrm{H}_{2} \mathrm{O}_{2}$ may also activate $\mathrm{K}_{\mathrm{Ca}}$ channels, resulting in vasorelaxation in rat cerebral arterioles (41). By contrast, $\mathrm{H}_{2} \mathrm{O}_{2}$ activates ATP-sensitive $\mathrm{K}^{+}$channels and causes vasorelaxation in cat cerebral arteriole (44). In the present study, activation of TBA-sensitive $\mathrm{K}_{\mathrm{Ca}}$ channels on the smooth muscle by $\mathrm{H}_{2} \mathrm{O}_{2}$ should play a central role in causing the relaxation and hyperpolarization, for the following reasons. First, relaxation to $\mathrm{H}_{2} \mathrm{O}_{2}$ and relaxation to ACh were both inhibited by pretreatment with TBA, a potent inhibitor of $\mathrm{K}_{\mathrm{Ca}}$ channels. Second, $\mathrm{H}_{2} \mathrm{O}_{2}$ caused relaxation and hyperpolarization in blood vessels without the endothelium. Third, $\mathrm{H}_{2} \mathrm{O}_{2}$ production by the endothelium was directly confirmed by confocal microscopy. The combination of apamin plus CTx partially but significantly inhibited the ACh-induced EDHF-mediated relaxation in endothelium-intact mesenteric arteries, whereas the combination of the two inhibitors did not affect $\mathrm{H}_{2} \mathrm{O}_{2}$-induced relaxation in endothelium-stripped arteries. This combination of apamin and CTx has been recently suggested to inhibit $\mathrm{K}_{\mathrm{Ca}}$ channels on the endothelium $(12,45)$, although the role of $\mathrm{K}_{\mathrm{Ca}}$ channels on the endothelium remains to be fully elucidated. Lack of the inhibitory effect of apamin plus $C T x$ on the $\mathrm{H}_{2} \mathrm{O}_{2}$-induced relaxation suggests that this combination may affect $\mathrm{K}_{\mathrm{Ca}}$ channels on the endothelium and may inhibit the production of EDHF. Indeed, a previous report suggests that depolarization of the endothelium (by a $\mathrm{K}_{\mathrm{Ca}}$ channel blocker) decreases agonist-induced $\mathrm{Ca}^{2+}$ influx (46), which is essential for production of EDHF (47).

It is also reported that $\mathrm{H}_{2} \mathrm{O}_{2}$ elicits hyperpolarization of human endothelial cells by activating their $\mathrm{K}_{\mathrm{Ca}}$ channels (48). $\mathrm{H}_{2} \mathrm{O}_{2}$-induced activation of $\mathrm{K}_{\mathrm{Ca}}$ channels on the endothelium results in both hyperpolarization of endothelial cells and $\mathrm{K}^{+}$release from those cells (12). Hyperpolarization of the endothelium can lead to hyperpolarization of the underlying smooth muscle via myoendothelial gap junctions (16), whereas $\mathrm{K}^{+}$can elicit hyperpolarization by activating $\mathrm{Na} / \mathrm{K}$ pump and inward rectifier $\mathrm{K}^{+}$channels on the smooth muscle (12). Thus, it is also conceivable that endotheliumderived $\mathrm{H}_{2} \mathrm{O}_{2}$ acts not only as a paracrine factor on the underlying vascular smooth muscle but also as an autocrine factor on the endothelium. However, this autocrine mechanism may not play a central role in mouse small mesenteric arteries, partly because inhibition of gap junctions by $18 \beta$-GA had no significant inhibitory effect on the EDHF-mediated relaxation and partly because $\mathrm{K}^{+}$may not be involved in the EDHFmediated relaxation of this blood vessel.

Physiological and pathophysiological implications. In the present study, a role for $\mathrm{H}_{2} \mathrm{O}_{2}$ as an EDRF in small mesenteric arteries was unmasked in control mice following the inhibition of $\mathrm{NO}$ production. Conversely, $\mathrm{NO}$ acted as the primary EDRF when $\mathrm{H}_{2} \mathrm{O}_{2}$ was reduced by catalase. Thus, $\mathrm{NO}$ and $\mathrm{H}_{2} \mathrm{O}_{2}$ (as an EDHF) 
appear to compensate each other to cause endothelium-dependent relaxation. Therefore, the notion that $\mathrm{H}_{2} \mathrm{O}_{2}$ is an endogenous EDHF may well explain the redundancy of the endothelium-dependent relaxation caused by NO and $\operatorname{EDHF}(1)$, as well as the inhibitory effect of NO on the EDHF activity $(32,33)$. SOD may play an essential role in mediating endotheliumdependent relaxation, not only by prolonging the halflife of $\mathrm{NO}$ but also by converting vasoconstrictor superoxide into vasodilating $\mathrm{H}_{2} \mathrm{O}_{2}$, an endogenous EDHF. It is controversial whether SOD is able to improve endothelial vasodilator function $(49,50)$. However, the enzyme might affect EDHF activity by either accelerating the rate at which $\mathrm{H}_{2} \mathrm{O}_{2}$ is generated or affecting the yield of $\mathrm{H}_{2} \mathrm{O}_{2}$ (i.e., by promoting superoxide dismutation) in microvessels, where EDHF operates as a major vasodilatory factor.

In summary, the present results indicate that endothelium-derived $\mathrm{H}_{2} \mathrm{O}_{2}$ is an EDHF in small mesenteric arteries of mice and that eNOS is a major source of the reactive oxygen species. The present concept may open a new research field on the importance and complexity of EDRFs under physiological and pathophysiological conditions.

\section{Acknowledgments}

We thank P. Huang and M. Fishman (Harvard Medical School) for providing the eNOS-KO mice, K. Takeshige (Kyushu University Graduate School of Medical Sciences) for critical reading of the manuscript, and I. Kunihiro for excellent technical assistance in this study. This work was supported in part by grants 07307010, 10877111, and 12877114 from the Japanese Ministry of Education, Science, Sports and Culture (Tokyo, Japan).

1. Mombouli, J.V., and Vanhoutte, P.M. 1997. Endothelium-derived hyperpolarizing factor(s): updating the unknown. Trends. Pharmacol. Sci. 18:252-256.

2. Shimokawa, H. 1999. Primary endothelial dysfunction: atherosclerosis. J. Mol. Cell. Cardiol. 31:23-37.

3. Shimokawa, H., et al. 1999. Importance of endothelium-derived hyperpolarizing factor in human arteries. In Endothelium-derived hyperpolarizing factor. P.M. Vanhoutte, editor. Harwood Academic Publishers. Amsterdam, The Netherlands. 391-398.

4. Feletou, M., and Vanhoutte, P.M. 1988. Endothelium-dependent hyperpolarization of canine coronary smooth muscle. Br. J. Pharmacol. 93:515-524.

5. Chen, G., Suzuki, H., and Weston, A.H. 1988. Acetylcholine releases endothelium-derived hyperpolarizing factor and EDRF from rat blood vessels. Br. J. Pharmacol. 95:1165-1174

6. Rosolowsky, M., and Campbell, W.B. 1993. Role of $\mathrm{PGI}_{2}$ and epoxyeicosatrienoic acids in relaxation of bovine coronary arteries to arachidonic acid. Am. J. Physiol. 264:H327-H335.

7. Hecker, M., Bara, A.T., Bauersachs, J., and Busse, R. 1994. Characterization of endothelium-derived hyperpolarizing factor as a cytochrome P450-derived arachidonic acid metabolite in mammals. J. Physiol. 481:407-414.

8. Fisslthaler, B., et al. 1999. Cytochrome P450 2C is an EDHF synthase in coronary arteries. Nature. 401:493-497.

9. Zygmunt, P.M., Edwards, G., Weston, A.H., Davis, S.C., and Hogestatt, E.D. 1996. Effects of cytochrome P450 inhibitors on EDHFmediated relaxation in the rat hepatic artery. Br. J. Pharmacol. 118:1147-1152.

10. Vanheel, B., and Van de Voorde, J. 1997. Evidence against the involvement of cytochrome P450 metabolites in endothelium-dependent hyperpolarization of the rat main mesenteric artery. J. Physiol. 501:331-341.

11. Fulton, D., McGiff, J.C., Wolin, M.S., Kaminski, P., and Quilley, J.
1997. Evidence against a cytochrome P450-derived reactive oxygen species as the mediator of the nitric oxide-independent vasodilator effect of bradykinin in the perfused heart of the rat. J. Pharmacol. Exp. Ther. 280:702-709.

12. Edwards, G., Dora, K.A., Gardener, M.J., Garland, C.J., and Weston, A.H. 1998. $\mathrm{K}+$ is an endothelium-derived hyperpolarizing factor in rat arteries. Nature. 396:269-272.

13. Quignard, J.F., et al. 1999. Potassium ions and endothelium-derived hyperpolarizing factor in guinea- pig carotid and porcine coronary arteries. Br. J. Pharmacol. 127:27-34.

14. Lacy, P.S., et al. 2000. Evidence against potassium as an endothelium-derived hyperpolarizing factor in rat mesenteric small arteries. Br. J. Pharmacol. 129:605-611.

15. Yamamoto, Y., Fukuta, H., Nakahira, Y., and Suzuki, H. 1998. Blockade by 18 beta-glycyrrhetinic acid of intercellular electrical coupling in guinea-pig arterioles. J. Physiol. 511:501-508.

16. Edwards, G., et al. 2000. Role of gap junctions and EETs in endothelium-dependent hyperpolarization of porcine coronary artery. Br.J. Pharmacol. 129:1145-1154.

17. Nagao, T., Illiano, S., and Vanhoutte, P.M. 1992. Calmodulin antagonists inhibit endothelium-dependent hyperpolarization in the canine coronary artery. Br. J. Pharmacol. 107:382-386.

18. Stroes, E., et al. 1998. Origin of superoxide production by endothelial nitric oxide synthase. FEBS Lett. 438:161-164.

19. Rubanyi, G.M., and Vanhoutte, P.M. 1986. Oxygen-derived free radicals, endothelium, and responsiveness of vascular smooth muscle. Am. J. Physiol. 250:H815-H821.

20. Beny, J.L., and von der Weid, P.Y. 1991. Hydrogen peroxide: an endogenous smooth muscle cell hyperpolarizing factor. Biochem. Biophys. Res. Commun. 176:378-384.

21. Barlow, R.S., and White, R.E. 1998. Hydrogen peroxide relaxes porcine coronary arteries by stimulating $\mathrm{BK}_{\mathrm{Ca}}$ channel activity. $\mathrm{Am}$. J. Physiol. 275:H1283-H1289.

22. Hayabuchi, Y., Nakaya, Y., Matsuoka, S., and Kuroda, Y. 1998. Hydrogen peroxide-induced vascular relaxation in porcine coronary arteries is mediated by $\mathrm{Ca}^{2+}$-activated $\mathrm{K}^{+}$channels. Heart Vessels. 13:9-17.

23. Huang, P.L., et al. 1995. Hypertension in mice lacking the gene for endothelial nitric oxide synthase. Nature. 377:239-242.

24. Shimokawa, H., et al. 1996. The importance of the hyperpolarizing mechanism increases as the vessel size decreases in endotheliumdependent relaxations in rat mesenteric circulation. J. Cardiovasc. Pharmacol. 28:703-711.

25. Urakami-Harasawa, L., Shimokawa, H., Nakashima, M., Egashira, K., and Takeshita, A. 1997. Importance of endothelium-derived hyperpolarizing factor in human arteries. J. Clin. Invest. 100:2793-2799.

26. Aoki, H., Kobayashi, S., Nishimura, J., and Kanaide, H. 1994. Sensitivity of G-protein involved in endothelin-1-induced $\mathrm{Ca}^{2+}$ influx to pertussis toxin in porcine endothelial cells in situ. Br. J. Pharmacol. 111:989-996.

27. Hirano, K., Hirano, M., and Kanaide, H. 1993. Enhancement by captopril of bradykinin-induced calcium transients in cultured endothelial cells of the bovine aorta. Eur. J. Pharmacol. 244:133-137.

28. Ohba, M., Shibanuma, M., Kuroki, T., and Nose, K. 1994. Production of hydrogen peroxide by transforming growth factor-beta 1 and its involvement in induction of egr-1 in mouse osteoblastic cells. $J$. Cell Biol. 126:1079-1088.

29. Gordon, T., et al. 1987. Apparent effect of catalase on airway edema in guinea pigs. Role of endotoxin contamination. Am. Rev. Respir. Dis. 135:854-859

30. Chataigneau, T., et al. 1999. Acetylcholine-induced relaxation in blood vessels from endothelial nitric oxide synthase knockout mice. Br. J. Pharmacol. 126:219-226.

31. Godecke, A., et al. 1998. Coronary hemodynamics in endothelial NO synthase knockout mice. Circ. Res. 82:186-194.

32. Bauersachs, J., et al. 1996. Nitric oxide attenuates the release of endothelium-derived hyperpolarizing factor. Circulation. 94:3341-3347.

33. Olmos, L., Mombouli, J.V., Illiano, S., and Vanhoutte, P.M. 1995. cGMP mediates the desensitization to bradykinin in isolated canine coronary arteries. Am. J. Physiol. 268:H865-H870.

34. Faraci, F.M., Sigmund, C.D., Shesely, E.G., Maeda, N., and Heistad, D.D. 1998. Responses of carotid artery in mice deficient in expression of the gene for endothelial NO synthase. Am. J. Physiol. 274:H564-H570.

35. Fujii, K., et al. 1992. Decreased endothelium-dependent hyperpolarization to acetylcholine in smooth muscle of the mesenteric artery of spontaneously hypertensive rats. Circ. Res. 70:660-669.

36. Wylam, M.E., et al. 1990. Endotoxin in vivo impairs endotheliumdependent relaxation of canine arteries in vitro. Am. Rev. Respir. Dis. 142:1263-1267. 
37. Huang, A., et al. 2000. In eNOS knockout mice skeletal muscle arteriolar dilation to acetylcholine is mediated by EDHF. Am. J. Physiol. 278:H762-H768.

38. Brandes, R.P., et al. 2000. An endothelium-derived hyperpolarizing factor distinct from $\mathrm{NO}$ and prostacyclin is a major endotheliumdependent vasodilator in resistance vessels of wild-type and endothelial NO synthase knockout mice. Proc. Natl. Acad. Sci. USA. 97:9747-9752.

39. Katusic, Z.S. 1996. Superoxide anion and endothelial regulation of arterial tone. Free. Radic. Biol. Med. 20:443-448.

40. Cosentino, F., et al. 1998. Tetrahydrobiopterin alters superoxide and nitric oxide release in prehypertensive rats. J. Clin. Invest. 101:1530-1537.

41. Sobey, C.G., Heistad, D.D., and Faraci, F.M. 1997. Mechanisms of bradykinin-induced cerebral vasodilatation in rats. Evidence that reactive oxygen species activate $\mathrm{K}^{+}$channels. Stroke. 28:2290-2294.

42. Pomposiello, S., Rhaleb, N.E., Alva, M., and Carretero, O.A. 1999. Reactive oxygen species: role in the relaxation induced by bradykinin or arachidonic acid via EDHF in isolated porcine coronary arteries. J. Cardiovasc. Pharmacol. 34:567-574.

43. Barlow, R.S., El-Mowafy, A.M., and White, R.E. 2000. $\mathrm{H}_{2} \mathrm{O}_{2}$ opens $\mathrm{BK}_{\mathrm{Ca}}$ channels via the $\mathrm{PLA}_{2}$-arachidonic acid signaling cascade in coronary artery smooth muscle. Am. J. Physiol. 279:H475-H483.
44. Wei, E.P., Kontos, H.A., and Beckman, J.S. 1996. Mechanisms of cerebral vasodilation by superoxide, hydrogen peroxide, and peroxynitrite. Am. J. Physiol. 271:H1262-H1266.

45. Edwards, G., et al. 1999. Further investigation of endotheliumderived hyperpolarizing factor (EDHF) in rat hepatic artery: studies using 1-EBIO and ouabain. Br. J. Pharmacol. 128:1064-1070.

46. Luckhoff, A., and Busse, R. 1990. Calcium influx into endothelial cells and formation of endothelium-derived relaxing factor is controlled by the membrane potential. Pflugers Arch. 416:305-311.

47. Chen, G.F., and Suzuki, H. 1990. Calcium dependency of the endothelium-dependent hyperpolarization in smooth muscle cells of the rabbit carotid artery. J. Physiol. 421:521-534.

48. Bychkov, R., et al. 1999. Hydrogen peroxide, potassium currents, and membrane potential in human endothelial cells. Circulation. 99:1719-1725.

49. Mugge, A., et al. 1991. Chronic treatment with polyethylene-glycolated superoxide dismutase partially restores endothelium-dependent vascular relaxations in cholesterol-fed rabbits. Circ. Res. 69:1293-1300.

50. Miller, F.J., Jr., Gutterman, D.D., Rios, C.D., Heistad, D.D., and Davidson, B.L. 1998. Superoxide production in vascular smooth muscle contributes to oxidative stress and impaired relaxation in atherosclerosis. Circ. Res. 82:1298-1305. 